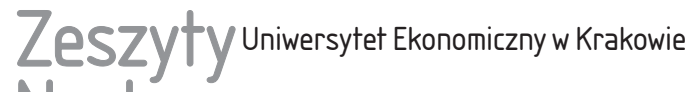 Naukowe
}

8(956)

ISSN 1898-6447

Zesz. Nauk. UEK, 2016; 8 (956): 35-49

DOI: 10.15678/ZNUEK.2016.0956.0803

Iwona Kik

Bartłomiej Marona

Adam Nalepka

\section{Wykorzystanie środków zwrotnych na realizację inwestycji gmin w województwie małopolskim*}

\section{Streszczenie}

Głównym celem opracowania jest identyfikacja uwarunkowań wyboru zwrotnych źródeł finansowania inwestycji przez gminy w Polsce oraz ocena zakresu wykorzystania środków zwrotnych na realizację projektów inwestycyjnych w gminach województwa małopolskiego. W artykule postawiono hipotezę badawczą, zgodnie z którą gminy miejskie częściej niż inne realizują inwestycje z wykorzystaniem środków zwrotnych.

Aby zrealizować cele i zweryfikować hipotezę, dokonano analizy literatury przedmiotu oraz zrealizowano badania empiryczne opierające się na danych Głównego Urzędu Statystycznego i Regionalnej Izby Obrachunkowej w Krakowie. Do zweryfikowania hipotezy badawczej zastosowano metodę analizy skupień. Przedmiotem badań były wszystkie gminy województwa małopolskiego (182 gminy).

Iwona Kik, e-mail: i.kik@onet.pl

Bartłomiej Marona, Uniwersytet Ekonomiczny w Krakowie, Katedra Ekonomiki Nieruchomości i Procesu Inwestycyjnego, 31-510 Kraków, ul. Rakowicka 27, e-mail: maronab@uek.krakow.pl Adam Nalepka, Uniwersytet Ekonomiczny w Krakowie, Katedra Ekonomiki Nieruchomości i Procesu Inwestycyjnego, 31-510 Kraków, ul. Rakowicka 27, e-mail: nalepkaa@uek.krakow.pl

Artykuł powstał w ramach projektu badawczego sfinansowanego ze środków przyznanych w 2016 r. Wydziałowi Ekonomii i Stosunków Międzynarodowych Uniwersytetu Ekonomicznego w Krakowie w ramach dotacji na utrzymanie potencjału badawczego. 
Słowa kluczowe: środki zwrotne, inwestycje gmin, finansowanie inwestycji, gmina.

Klasyfikacja JEL: H71, H72, P43.

\section{Wprowadzenie}

Problematyka wykorzystania zwrotnych źródeł finansowania inwestycji jest istotna ze względu na spotykany często brak adekwatności pomiędzy poziomem środków finansowych, którymi dysponują gminy, a rozmiarem zadań przekazanych im do realizacji. Środki własne gmin nie wystarczają na sfinansowanie zadań bieżących i potrzeb inwestycyjnych. Dlatego też gminy stają przed koniecznością poszukiwania dodatkowych, zewnętrznych źródeł finansowania inwestycji. Problem ten jest szczególnie aktualny w sytuacji, w której transfery do budżetu gmin z tytułu udziału w podatku dochodowym od osób fizycznych mogą zostać w najbliższym czasie uszczuplone na skutek konieczności podniesienia kwoty wolnej od podatku ${ }^{1}$.

Celem niniejszego artykułu jest identyfikacja uwarunkowań wyboru zwrotnych źródeł finansowania inwestycji przez gminy w Polsce oraz ocena zakresu wykorzystania środków zwrotnych na realizację projektów inwestycyjnych w gminach województwa małopolskiego. Na podstawie wstępnej analizy literatury postawiono hipotezę badawczą, zgodnie z którą gminy miejskie częściej niż inne realizują inwestycje z wykorzystaniem środków zwrotnych. Aby zrealizować cele i zweryfikować hipotezę, w artykule dokonano analizy literatury przedmiotu oraz przeprowadzono badania empiryczne opierające się na danych Głównego Urzędu Statystycznego i Regionalnej Izby Obrachunkowej w Krakowie. Stosując analizę skupień, wyróżniono grupy gmin z województwa małopolskiego charakteryzujące się podobnym stopniem wykorzystania środków zwrotnych. Podjęto także próbę znalezienia zależności, które mogłyby wyjaśnić, dlaczego pewne gminy częściej niż inne sięgają po środki zwrotne przy realizacji projektów inwestycyjnych.

\section{Specyfika inwestycji gmin i ich finansowanie}

Definicja pojęcia inwestycji gmin jest kwestią dyskusyjną zarówno w teorii, jak i w praktyce gospodarczej [Hermaszewski 2006, s. 5]. Wielu specjalistów zajmujących się problematyką samorządów terytorialnych zamiennie stosuje takie określenia, jak: inwestycje lokalne, inwestycje gminne, inwestycje komunalne czy też inwestycje infrastrukturalne. Spotkać można też takie terminy jak inwestycje samorządu terytorialnego i inwestycje publiczne. Zestawienie określeń wystę-

\footnotetext{
${ }^{1}$ Wyrok w imieniu Rzeczypospolitej Polskiej z dnia 28 października 2015 r. Sygn. akt K 21/14.
} 
pujących w literaturze wskazuje na różne rozumienie pojęcia inwestycji gmin (tabela 1).

Tabela 1. Wybrane definicje inwestycji podejmowanych przez gminy

\begin{tabular}{|c|c|c|}
\hline Autor & Określenie & Definicja \\
\hline M. Zioło & $\begin{array}{l}\text { Inwestycje } \\
\text { jednostek } \\
\text { samorządu } \\
\text { terytorialnego }\end{array}$ & $\begin{array}{l}\text { Inwestycje o charakterze infrastrukturalnym, technicznym, } \\
\text { integrowane z zadaniami własnymi jednostek samorządu } \\
\text { terytorialnego, wspierające ich realizację, kreujące wartość } \\
\text { dodaną na poziomie jednostki terytorialnej i zwiększające } \\
\text { jej konkurencyjność przez podnoszenie zdolności jednostek } \\
\text { samorządu terytorialnego do wzrostu i rozwoju }\end{array}$ \\
\hline J. Czempas & $\begin{array}{l}\text { Inwestycje } \\
\text { samorządu } \\
\text { terytorialnego }\end{array}$ & $\begin{array}{l}\text { Przez inwestycje samorządu terytorialnego należy rozumieć } \\
\text { obarczone ryzykiem celowe wydatkowanie kapitału, ukie- } \\
\text { runkowane na powiększenie korzyści materialnych i niema- } \\
\text { terialnych wspólnoty samorządowej oraz na powiększenie } \\
\text { możliwości wzrostu jakości oraz zakresu dostarczanych } \\
\text { dóbr i usług }\end{array}$ \\
\hline $\begin{array}{l}\text { H. Kurek } \\
\text { i H. Zielińska }\end{array}$ & $\begin{array}{l}\text { Inwestycje } \\
\text { komunalne }\end{array}$ & $\begin{array}{l}\text { Wszystkie inwestycje prowadzone przez przedsiębiorstwa } \\
\text { komunalne, jednostki samorządu terytorialnego lub ich jed- } \\
\text { nostki pomocnicze }\end{array}$ \\
\hline M. Graczyk & $\begin{array}{l}\text { Inwestycje } \\
\text { komunalne }\end{array}$ & $\begin{array}{l}\text { Techniczne instrumenty stymulowania zrównoważonego } \\
\text { rozwoju (ładu zintegrowanego), ponieważ ich realizacja } \\
\text { wpływa na ogólną poprawę stanu środowiska (ład ekolo- } \\
\text { giczny) i jakości życia mieszkańców (ład społeczny), a jed- } \\
\text { nocześnie rzutuje w istotny sposób na rozwój gospodarczy } \\
\text { gminy (ład ekonomiczny) }\end{array}$ \\
\hline $\begin{array}{l}\text { C. Rudzka- } \\
\text {-Lorentz } \\
\text { i J. Sierak }\end{array}$ & Inwestycje gmin & $\begin{array}{l}\text { Wydatki na zakup lub wytworzenie materialnych skład- } \\
\text { ników majątkowych związanych z realizacją ustawowych } \\
\text { zadań mianem inwestycji gmin; obejmują one działania } \\
\text { z zakresu użyteczności publicznej i mają charakter niedo- } \\
\text { chodowy }\end{array}$ \\
\hline
\end{tabular}

Źródło: opracowanie własne na podstawie [Nowe zarzadzanie... 2005, s. 162-163; Kurek i Zielińska 2007, s. 140; Graczyk 2008, s. 48; Zioło 2012, s. 17; Czempas 2013, s. 26].

Mimo różnorodności interpretacyjnych jako podstawowy cel inwestycji realizowanych przez gminy przyjmuje się poprawę warunków życia społeczności lokalnej i zaspokojenie potrzeb użyteczności publicznej. Inwestycje gmin są zatem instrumentem oddziaływania na lokalny rozwój społeczno-gospodarczy.

Aby możliwa była realizacja projektów inwestycyjnych, konieczne jest zagwarantowanie odpowiedniego poziomu środków finansowych. W Polsce występują liczne możliwości finansowania inwestycji, z których część jest typowa dla sektora publicznego, natomiast inne formy zostały wzięte $\mathrm{z}$ sektora przedsiębiorstw. 
Źródła finansowania inwestycji gmin są różnie klasyfikowane. Najogólniej można podzielić je na wewnętrzne, zewnętrzne oraz inne (rys. 1).

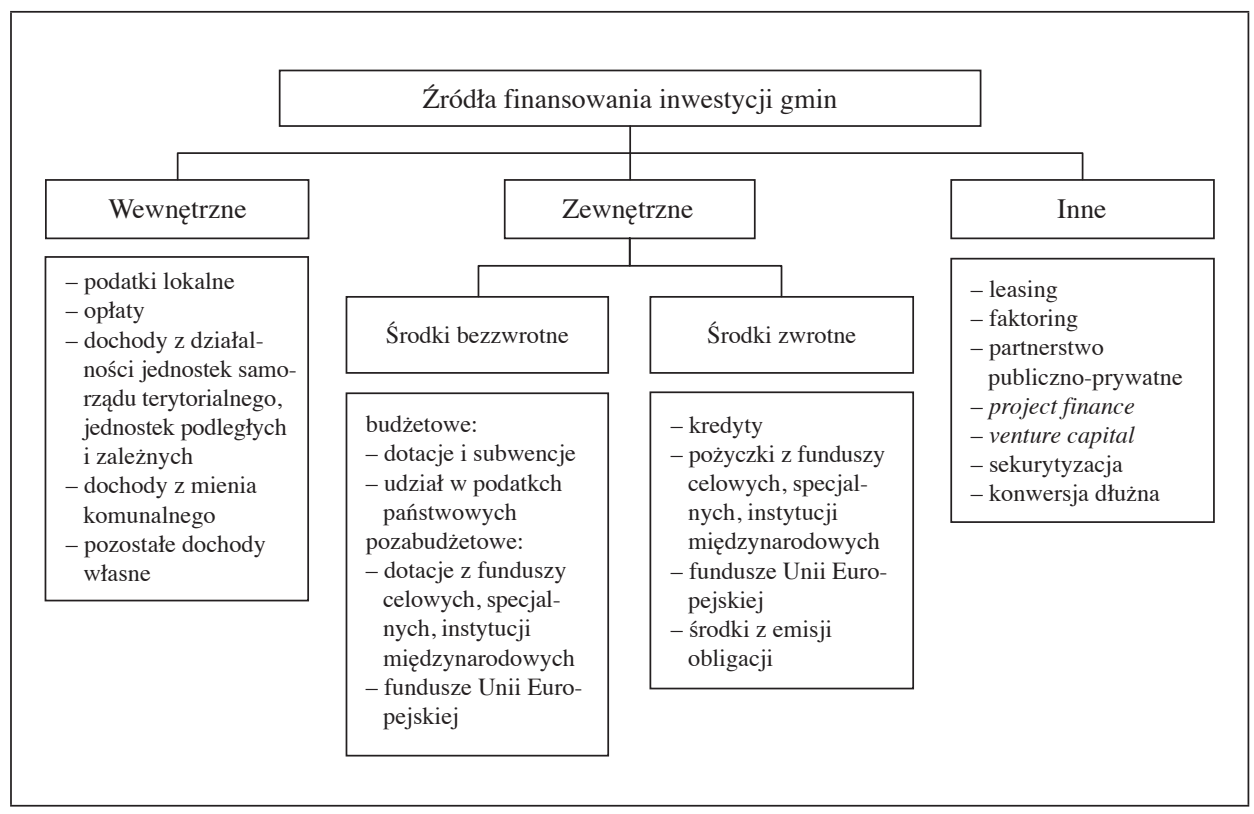

Rys. 1. Źródła finansowania inwestycji gmin

Źródło: opracowanie własne na podstawie [Bankowo-finansowa obsługa...2008, s. 23; Guziejewska 2008, s. 45-46; Zioło 2012, s. 70-71].

W grupie wewnętrznych źródeł finansowania znajdują się dochody własne, m.in. wpływy z podatków (np. od nieruchomości, rolnego, leśnego), opłat (np. skarbowej, targowej, miejscowej), dochody uzyskiwane przez gminne jednostki budżetowe i wpłaty od samorządowych zakładów budżetowych, dochody z majątku gminy, spadki, zapisy i darowizny na rzecz gminy.

Zewnętrzne źródła obejmują środki bezzwrotne oraz zwrotne. Źródła bezzwrotne to środki budżetowe (tj. dotacje i subwencje oraz udział w podatkach państwowych) oraz pozabudżetowe (tj. fundusze Unii Europejskiej oraz dotacje z funduszy celowych, specjalnych i instytucji międzynarodowych). Do źródeł zwrotnych zalicza się kredyty, pożyczki i środki z emisji obligacji.

Inne źródła to przede wszystkim złożone formy finansowania: partnerstwo publiczno-prywatne [Węgrzyn 2013, s. 125-126], project finance, venture capital, sekurytyzacja aktywów, konwersja dłużna, a także leasing oraz faktoring. 


\section{Uwarunkowania wyboru zwrotnych źródeł finansowania}

W warunkach utrzymującego się niedoboru środków finansowych na realizację koniecznych przedsięwzięć inwestycyjnych w zaspokajaniu potrzeb społeczności lokalnych coraz większą rolę odgrywają zwrotne źródła finansowania, pochodzące z kredytów, pożyczek oraz emisji papierów wartościowych. Tego typu źródła finansowania umożliwiają władzom gmin realizację inwestycji oraz zwiększenie poziomu realizowanych inwestycji.

W literaturze przedmiotu wskazuje się na pozytywne aspekty finansowania inwestycji gmin środkami zwrotnymi. Wśród nich wymienia się [Wiewióra 2009, s. 10-11]:

- przyśpieszenie okresu realizacji przedsięwzięcia inwestycji, co skutkuje obniżeniem kosztów inwestycji,

- potencjalne korzyści z inwestycji, które przekraczają koszty obsługi zadłużenia,

- równość międzypokoleniową - każde pokolenie czerpie korzyści z inwestycji i partycypuje w spłacie zobowiązań zaciągniętych na jej realizację (realizacja zasady: ,płać, skoro korzystasz”),

- poprawę absorpcji środków unijnych, które wymagają zapewnienia wkładów własnych (tj. udziału własnego, który może być wniesiony w formie kredytów inwestycyjnych).

O wyborze zewnętrznych źródeł finansowania decydują różne kryteria, które można ująć w trzy grupy [Filipiak 2014, s. 34]: czynniki zewnętrzne, czynniki wewnętrzne oraz czynniki wynikające ze specyfiki instrumentu dłużnego (tabela 2).

Czynniki zestawione w tabeli 2 wskazują, że decyzja o wyborze zwrotnych źródeł finansowania inwestycji jest wypadkową różnych czynników. Ponadto niektóre gminy mają większe predyspozycje do zaciągania zobowiązań niż inne (np. ze względu na wewnętrzną sytuację finansową lub wzmożoną aktywność inwestycyjną). Ponieważ decydenci w gminie napotykają wiele problemów wynikających z niepełnej informacji i ograniczonych możliwości analizy, na ich decyzje wpływają też czynniki behawioralne, tj.: czynniki psychologiczne i błędy poznawcze (zob. [Zielonka 2008, s. 49; Zielińska i Ostrowska 2013, s. 489; Czerwonka 2015, s. 60]). Oznacza to, że wybór źródła finansowania może wynikać z charakteru lub cech osobowości urzędnika, jego dotychczasowych doświadczeń i posiadanej wiedzy.

Z jednej strony środki zwrotne pozwalają gminom na zwiększenie nakładów inwestycyjnych, $\mathrm{z}$ drugiej jednak powodują zaciągnięcie zobowiązania finansowego o określonych kosztach i terminach spłat, co ma wpływ na ustawowe ograniczenia dotyczące zaciągania długu. Art. 243 ustawy o finansach publicznych 
[Ustawa z dnia 27 sierpnia 2009] określa limit w postaci indywidualnego wskaźnika zadłużenia. Zgodnie z nim roczna wartość relacji spłat zobowiązań i ich obsługi do planowanych dochodów nie może przekraczać wskaźnika obliczonego jako średnia arytmetyczna z wyliczonych dla ostatnich trzech lat poprzedzających dany rok budżetowy relacji dochodów bieżących, powiększonych o dochody uzyskane ze sprzedaży majątku oraz pomniejszonych o wydatki bieżące do dochodów ogółem budżetu.

Tabela 2. Determinanty wyboru zwrotnych źródeł finansowania

\begin{tabular}{|c|c|}
\hline Grupa czynników & Determinanty \\
\hline Zewnętrzne & $\begin{array}{l}\text { - obowiązujące przepisy prawa } \\
\text { - sytuacja społeczno-gospodarcza } \\
\text { - sytuacja na rynkach finansowych } \\
\text { - czynniki związane z ryzykiem zewnętrznym (np. polityczne, } \\
\text { prawne) }\end{array}$ \\
\hline Wewnętrzne & $\begin{array}{l}\text { - sytuacja finansowa gminy (np. poziom dochodów) } \\
\text { - budżet bieżący gminy } \\
\text { - sytuacja inwestycyjna (w tym zdolność do podejmowania nowych } \\
\text { inwestycji) } \\
\text { - wykorzystanie środków europejskich } \\
\text { - czynniki ryzyka wewnętrznego (np. finansowe, kadrowe) }\end{array}$ \\
\hline $\begin{array}{l}\text { Wynikające ze specyfiki } \\
\text { danego instrumentu }\end{array}$ & $\begin{array}{l}\text { - ryzyko transakcyjne i finansowe } \\
\text { - koszty pozyskania źródła i koszty obsługi długu } \\
\text { - czynniki miękkie (np. efekt promocyjny) } \\
\text { - czynniki związane z rynkami finansowymi, na których są emito- } \\
\text { wane lub dopuszczane do obrotu instrumenty dłużne (np. zasady } \\
\text { i procedury obowiązujące na rynkach, rozwój pośrednictwa finan- } \\
\text { sowego, dywersyfikacja ryzyka działalności i model klienta prefe- } \\
\text { rowanego) }\end{array}$ \\
\hline
\end{tabular}

Źródło: opracowanie własne na podstawie [Filipiak 2014, s. 40-42].

Zaciąganie zobowiązań finansowych nie tylko wpływa na ustawowe limity zadłużenia, ale przede wszystkim powoduje negatywne skutki dla przyszłych pokoleń, które muszą spłacać dług samorządowy. Mimo to korzystanie ze zwrotnych źródeł finansowania inwestycji przez gminy jest powszechne. Jedną z głównych przyczyn jest brak adekwatności pomiędzy wielkością posiadanych przez nie środków finansowych a liczbą i kapitałochłonnością powierzonych tym jednostkom zadań.

Aby określić zakres wykorzystania środków zwrotnych w finansowaniu inwestycji gmin oraz ocenić niektóre uwarunkowania, przeprowadzono badania empiryczne dla gmin w województwie małopolskim. Omówiono je w kolejnej części artykułu. 


\section{Wyniki badań własnych przeprowadzonych w gminach województwa małopolskiego}

Celem badań była identyfikacja zakresu wykorzystania środków zwrotnych na realizację projektów inwestycyjnych w gminach województwa małopolskiego. Dodatkowym, uszczegóławiającym celem było pogrupowanie gmin województwa małopolskiego ze względu na zakres wykorzystania środków zwrotnych.

Koszty realizacji usług publicznych w różnych typach gmin są różne. Ze względu na swoją specyfikę gminy miejskie muszą zaspokoić większą liczbę potrzeb mieszkańców niż gminy wiejskie, co implikuje konieczność poszukiwania dodatkowych źródeł finansowania. W związku z tym jako hipotezę badawczą przyjęto, że gminy miejskie częściej niż inne realizują inwestycje z wykorzystaniem środków zwrotnych.

Do zweryfikowania hipotezy badawczej zastosowano metodę analizy skupień, której celem jest uzyskanie jednorodnych grup analizowanych obiektów (w tym przypadku gmin) pod względem badanych cech. Analiza skupień obejmuje różne metody klasyfikacji obiektów - w niniejszych badaniach posłużono się metodą Warda i wykorzystano odległość euklidesową (zob. [Grabiński i Sokołowski 1984, s. 63-79; Malina 2004, s. 63; Suchecki 2010, s. 62]). Obliczenia wykonano w programie Statistica w module analiza skupień.

Przedmiotem badań są wszystkie gminy województwa małopolskiego (182 gminy), a dane do analizy pochodzą ze sprawozdań za 2014 r. opublikowanych przez Regionalną Izbę Obrachunkową w Krakowie. Jako zmienne do badań przyjęto trzy wskaźniki:

$\mathrm{X}_{1}$ - udział wydatków inwestycyjnych w wydatkach ogółem - wskazuje on na rodzaj polityki inwestycyjnej gmin: im wyższa wartość, tym bardziej aktywne działania inwestycyjne prowadzi gmina, a to implikuje konieczność poszukiwania dodatkowych źródeł finansowania pozwalających na realizację inwestycji [Zioło 2012, s. 258-259];

$\mathrm{X}_{2}$ - relacja wydatków inwestycyjnych do wolnych środków (wolne środki to różnica między dochodami ogółem a wydatkami bieżącymi) - wydatki inwestycyjne przewyższające wysokość wolnych środków oznaczają, że gmina sięga do zwrotnych źródeł finansowania inwestycji [Jastrzębska 2009, s. 128-129];

$\mathrm{X}_{3}$ - relacja przychodów z zaciągniętych kredytów i pożyczek oraz emisji papierów wartościowych dłużnych do wydatków inwestycyjnych - informuje o stopniu finansowania wydatków inwestycyjnych zwrotnymi źródłami finansowania (pożyczki, kredyty, obligacje) [Jastrzębska 2009, s. 131-132]. 
Aby sprawdzić poprawność statystyczną doboru zmiennych, obliczono współczynniki zmienności ${ }^{2}$ i korelacji ${ }^{3}$. Otrzymane wyniki potwierdziły prawidłowy wybór zmiennych pod względem statystycznym:

- współczynniki zmienności: $X_{1}-0,47, X_{2}-0,39, X_{3}-0,91$;

- współczynniki korelacji: $\mathrm{X}_{1}$ i $\mathrm{X}_{2}-0,09, \mathrm{X}_{1}$ i $\mathrm{X}_{3}-0,03, \mathrm{X}_{2}$ i $\mathrm{X}_{3}-0,18$.

Kolejnym krokiem było doprowadzenie zmiennych do wzajemnej porównywalności. W tym celu wykorzystano metodę unitaryzacji i zastosowano następującą formułę [Młodak 2006, s. 39]:

$$
x_{i j}^{\prime}=\frac{x_{i j}-\min _{i} x_{i j}}{\max _{i} x_{i j}-\min _{i} x_{i j}},
$$

gdzie:

$i=1,2, \ldots, n$,

$j=1,2, \ldots, p$,

$\max _{i} x_{i j}$ - maksymalna wartość $j$-tej cechy w $i$-tym obiekcie,

$\min _{i} x_{i j}$ - minimalna wartość $j$-tej cechy w $i$-tym obiekcie.

Na podstawie otrzymanych wartości przeprowadzono analizę skupień w programie Statistica. W wyniku przeprowadzonej analizy za pomocą metody Warda oraz odległości euklidesowej powstał dendrogram zaprezentowany na rys. 2.

Grupowanie gmin pozwoliło na wyodrębnienie trzech grup skupień, które obejmują gminy podobne pod względem intensywności korzystania ze środków zwrotnych w finansowaniu inwestycji. Średnie arytmetyczne poszczególnych wskaźników w każdym skupieniu zaprezentowano w tabeli 3.

Wskaźniki przedstawione w tabeli 3 obliczone zostały na podstawie wartości rzeczywistych (przed unitaryzacją). W grupie pierwszej dwa wskaźniki - relacja wydatków inwestycyjnych do wolnych środków oraz relacja przychodów zwrotnych do wydatków inwestycyjnych, są zdecydowanie wyższe niż w pozostałych grupach. Udział wydatków inwestycyjnych w wydatkach ogółem jest jednak niższy w porównaniu z grupą drugą. Na podstawie analizy wskaźników oceniono, że pierwsza grupa to gminy, które w najwyższym stopniu wykorzystują środki zwrotne w finansowaniu inwestycji (skupienie 1). Druga grupa (skupienie 2) to gminy, które w średnim stopniu wykorzystują środki zwrotne w finansowaniu

${ }^{2}$ Małe zróżnicowanie współczynnika zmienności wskazuje, że dana zmienna słabo dyskryminuje badane obiekty, czyli ma małą wartość informacyjną. Ze zbioru cech eliminuje się te zmienne, dla których wartość współczynnika zmienności jest nie większa od pewnie ustalonej małej wartości progowej, przy czym zwykle przyjmowana jest wartość 0,1 .

${ }^{3}$ Wysoki współczynnik korelacji Pearsona między zmiennymi wskazuje, że są one nośnikami podobnych informacji i wtedy z danej pary wybiera się jedną zmienną, a drugą odrzuca (na podstawie przesłanek merytorycznych oraz statystyczno-formalnych). 


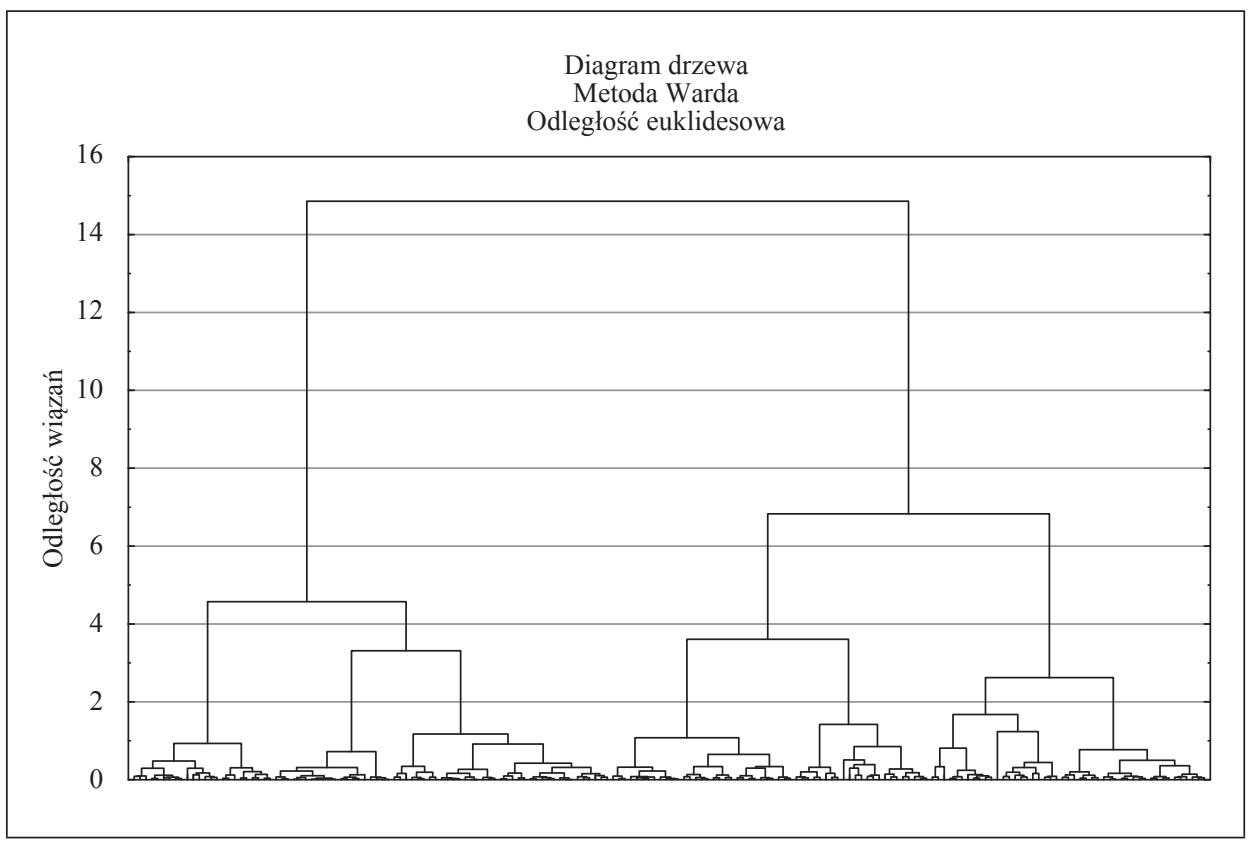

Rys 2. Grupowanie gmin województwa małopolskiego ze względu na wykorzystanie środków zwrotnych w finansowaniu inwestycji

Źródło: opracowanie własne.

Tabela 3. Średnie arytmetyczne wskaźników w poszczególnych grupach gmin

\begin{tabular}{|c|c|c|c|}
\hline Grupa gmin & $\begin{array}{c}\text { Udział wydatków } \\
\text { inwestycyjnych } \\
\text { w wydatkach ogółem }\end{array}$ & $\begin{array}{c}\text { Relacja wydatków } \\
\text { inwestycyjnych } \\
\text { do wolnych środków }\end{array}$ & $\begin{array}{c}\text { Relacja przychodów } \\
\text { zwrotnych do wydat- } \\
\text { ków inwestycyjnych }\end{array}$ \\
\hline Skupienie 1 & 0,1782 & 1,4321 & 0,6243 \\
\hline Skupienie 2 & 0,2614 & 1,1250 & 0,2431 \\
\hline Skupienie 3 & 0,1086 & 0,7666 & 0,1842 \\
\hline
\end{tabular}

Źródło: opracowanie własne na podstawie przeprowadzonych obliczeń.

inwestycji, ale udział ich wydatków inwestycyjnych w wydatkach ogółem jest największy (ponad 26\%) Natomiast trzecia grupa obejmuje gminy, które najrzadziej sięgają po środki zwrotne przy finansowaniu inwestycji (skupienie 3). Gminy wchodzące w skład poszczególnych grup zestawiono w tabeli 4.

Grupy pierwsza i druga zawierają zbliżoną liczbę gmin. Natomiast najliczniejsza jest grupa trzecia obejmująca 81 gmin (45\% badanych jednostek), które podczas realizacji inwestycji wykorzystują środki zwrotne w najmniejszym stopniu. $\mathrm{Na}$ rys. 3 zaznaczono obszar gmin wchodzących w skład poszczególnych skupień. 
Tabela 4. Skupienia gmin w województwie małopolskim o podobnym poziomie wykorzystania środków zwrotnych w finansowaniu inwestycji

\begin{tabular}{|c|c|}
\hline Skupienie & Gminy \\
\hline $\begin{array}{l}\text { Skupienie } 1 \\
\text { (47 gmin) }\end{array}$ & $\begin{array}{l}\text { Bochnia (1), Skała (3), Czarny Dunajec (2), Biskupice (2), Łososina Dolna (2), } \\
\text { Pleśna (2), Iwkowa (2), Łużna (2), Słaboszów (2), Tuchów (3), Charsznica (2), } \\
\text { Andrychów (3), Mogilany (2), Krościenko nad Dunajcem (2), Spytkowice (powiat } \\
\text { wadowicki; 2), Gorlice (2), Pcim (2), Miechów (3), Dębno (2), Zawoja (2), Lima- } \\
\text { nowa (2), Tymbark (2), Stryszawa (2), Tarnów (2), Niepołomice (3), Oświęcim } \\
\text { (1), Lipnica Murowana (2), Raciechowice (2), Gnojnik (2), Żegocina (2), Lisia } \\
\text { Góra (2), Radziemice (2), Radłów (3), Rzezawa (2), Czchów (3), Wierzchosła- } \\
\text { wice (2), Zakopane (1), Kęty (3), Borzęcin (2), Książ Wielki (2), Rzepiennik } \\
\text { Strzyżewski (2), Babice (2), Zabierzów (2), Żabno (3), Siepraw (2), Skrzyszów (2), } \\
\text { Piwniczna-Zdrój (3) }\end{array}$ \\
\hline $\begin{array}{l}\text { Skupienie } 2 \\
\text { (54 gminy) }\end{array}$ & $\begin{array}{l}\text { Bukowno (1), Słomniki (3), Szczurowa (2), Kościelisko (2), Podegrodzie (2), } \\
\text { Drwinia (2), Liszki (2), Jodłownik (2), Limanowa (1), Nowy Targ (1), Muszyna } \\
\text { (3), Ropa (2), Sułkowice (3), Wielka Wieś (2), Bukowina Tatrzańska (2), Dobra (2), } \\
\text { Skawina (3), Myślenice (3), Gołcza (2), Łapsze Niżne (2), Jabłonka (2), Pałecznica } \\
\text { (2), Łącko (2), Mszana Dolna (1), Jordanów (2), Kraków (1), Gdów (2), Tomice } \\
\text { (2), Lipinki (2), Koszyce (2), Dąbrowa Tarnawska (3), Sułoszowa (2), Bobowa (3), } \\
\text { Korzenna (2), Stary Sącz (3), Nowy Targ (2), Wieliczka (3), Mszana Dolna (2), } \\
\text { Zakliczyn (3), Wieprz (2), Dobczyce (3), Rabka-Zdrój (3), Sucha Beskidzka (1), } \\
\text { Zielonki (2), Raba Wyżna (2), Przeciszów (2), Kamienica (2), Michałowice (2), } \\
\text { Zembrzyce (2), Trzyciąż (2), Sękowa (2), Czorsztyn (2), Zator (3), Racławice (2) }\end{array}$ \\
\hline $\begin{array}{l}\text { Skupienie } 3 \\
(81 \text { gmin })\end{array}$ & $\begin{array}{l}\text { Gorlice (1), Mucharz (2), Świątniki Górne (3), Iwanowice (2), Olesno (2), Laskowa } \\
\text { (2), Biały Dunajec (2), Spytkowice (powiat nowotarski; 2); Kamionka Wielka (2), } \\
\text { Kocmyrzów-Luborzyca (2), Wolbrom (3), Oświęcim (2), Radgoszcz (2), Olkusz } \\
\text { (3), Bolesław (powiat olkuski; 2), Igołomia-Wawrzeńczyce (2), Kłaj (2), Moszcze- } \\
\text { nica (2), Chrzanów (3), Chełmiec (2), Wojnicz (3), Szczawnica (3), Grybów (2), } \\
\text { Osiek (2), Słopnice (2), Łabowa (2), Uście Gorlickie (2), Nawojowa (2), Niedź- } \\
\text { wiedź (2), Budzów (2), Klucze (2), Bystra-Sidzina (2), Kalwaria Zebrzydowska } \\
\text { (3), Chełmek (3), Koniusza (2), Mędrzechów (2), Proszowice (3), Grybów (1), } \\
\text { Gromnik (2), Wietrzychowice (2), Jordanów (1), Bolesław (powiat dąbrowski; 2), } \\
\text { Wiśniowa (2), Wadowice (3), Biecz (3), Nowy Wiśnicz (3), Gręboszów (2), } \\
\text { Trzciana (2), Lanckorona (2), Lipnica Wielka (2), Łapanów (2), Jerzmanowice- } \\
\text {-Przeginia (2), Tokarnia (2), Brzeszcze (3), Kozłów (2), Ochotnica Dolna (2), } \\
\text { Łukowica (2), Bochnia (3), Nowy Sącz (1), Polanka Wielka (2), Libiąż (3), Poro- } \\
\text { nin (2), Ryglice (3), Krynica-Zdrój (3), Szczucin (3), Tarnów (1), Brzeźnica (2), } \\
\text { Trzebinia (3), Gródek nad Dunajcem (2), Stryszów (2), Szerzyny (2), Lubień (2), } \\
\text { Czernichów (2), Szaflary (2), Krzeszowice (3), Maków Podhalański (3), Rytro (2), } \\
\text { Ciężkowice (3), Alwernia (3), Brzesko (3), Nowe Brzesko (3) }\end{array}$ \\
\hline
\end{tabular}

Objaśnienia: (1) - gmina miejska, (2) - gmina wiejska, (3) - gmina miejsko-wiejska.

Źródło: opracowanie własne. 


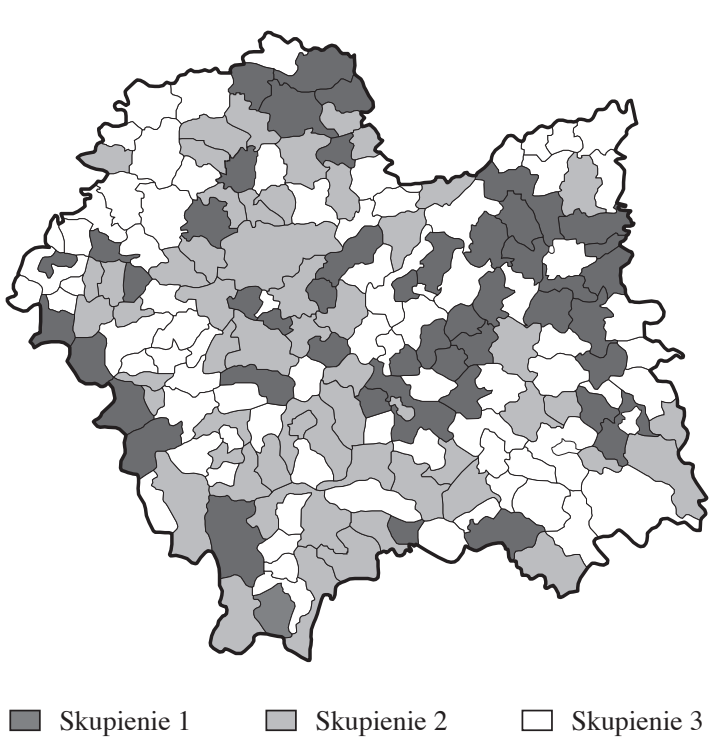

Rys. 3. Przestrzenne zróżnicowanie województwa małopolskiego pod względem wykorzystania środków zwrotnych w finansowaniu inwestycji gmin Źródło: opracowanie własne.

$\mathrm{Z}$ analizy rys. 3 wynika, że gminy w największym stopniu wykorzystujące finansowanie zwrotne przy realizacji inwestycji to przeważnie gminy leżące na północy i północnym wschodzie województwa małopolskiego (powiaty miechowski, brzeski i tarnowski). Gminy, które w najmniejszym stopniu wykorzystują środki zwrotne, rozproszone są po całym województwie. Można jednak wskazać powiaty, w których dominują gminy ze skupienia 3. Są to powiaty: olkuski, chrzanowski, dąbrowski i nowosądecki. W centralnej części województwa występują przede wszystkim gminy, które w średnim stopniu wykorzystują środki zwrotne w finansowaniu inwestycji. Szczegółowe informacje o typach gmin (miejska, wiejska, miejsko-wiejska) wchodzących w skład poszczególnych skupień zostały przedstawione w tabeli 5 .

Dane zestawione w tabeli 5 nie weryfikują hipotezy zakładającej, że gminy miejskie częściej niż inne wykorzystują środki zwrotne w finansowaniu inwestycji. Najliczniejszą grupą są gminy, które rzadko wykorzystują możliwości finansowania projektów inwestycyjnych ze środków zwrotnych. W skupieniu tym dominują przede wszystkim gminy wiejskie oraz miejsko-wiejskie. 
Tabela 5. Rodzaje gmin w poszczególnych skupieniach

\begin{tabular}{|l|c|c|c|}
\hline \multicolumn{1}{|c|}{ Rodzaj gminy } & Skupienie 1 & Skupienie 2 & Skupienie 3 \\
\hline Gminy miejskie (1) & 3 & 6 & 5 \\
\hline Gminy wiejskie (2) & 34 & 35 & 52 \\
\hline $\begin{array}{l}\text { Gminy miejsko- } \\
\text {-wiejskie (3) }\end{array}$ & 10 & 13 & 24 \\
\hline Razem & 47 & 54 & 81 \\
\hline
\end{tabular}

Źródło: opracowanie własne.

We wcześniejszej części opracowania zwrócono uwagę, że pewne gminy mają większą zdolność zaciągania zobowiązań niż inne, co może wynikać z ich sytuacji finansowej. Dlatego też kolejnym etapem analizy było określenie sytuacji finansowej gmin na podstawie wskaźnika zamożności (dochody ogółem na jednego mieszkańca $)^{4}$. Dla trzech wyodrębnionych grup w przeprowadzonej analizie skupień obliczono średnią arytmetyczną oraz medianę dochodów ogółem gminy przypadających na jednego mieszkańca (tabela 6).

Tabela 6. Dochody ogółem na jednego mieszkańca w poszczególnych skupieniach gmin (w zł)

\begin{tabular}{|l|c|c|c|}
\hline Wskaźnik & Skupienie 1 & Skupienie 2 & Skupienie 3 \\
\hline Średnia & 3036 & 3481 & 3113 \\
\hline Mediana & 3066 & 3358 & 2986 \\
\hline
\end{tabular}

Źródło: opracowanie własne na podstawie danych Głównego Urzędu Statystycznego.

Z przedstawionych danych liczbowych wynika, że gminy, w których dochód ogółem na jednego mieszkańca jest najwyższy, w średnim stopniu wykorzystują środki zwrotne w finansowaniu inwestycji. Taka zależność może wynikać z następujących przesłanek:

- gminy o bardzo dobrej sytuacji finansowej nie muszą korzystać ze środków zwrotnych na finansowanie inwestycji, gdyż posiadają wysokie dochody; z tego powodu nie należą do grupy pierwszej obejmującej gminy o najwyższym poziomie wykorzystania środków zwrotnych;

- gminy o bardzo dobrej sytuacji finansowej mogą osiągać wyższy poziom zadłużenia niż inne, gdyż w ich przypadku przekroczenie ustawowych limitów

${ }^{4}$ Wskaźnik ten określa, ile środków pieniężnych posiada dana gmina na jednego mieszkańca; im wyższa wartość wskaźnika, tym większa możliwość zaspokojenia potrzeb mieszkańców lub większa możliwość obsługi dodatkowego zadłużenia przy finansowaniu potrzeb (zob. [Wiśniewski 2011, s. 126]). 
zadłużenia jest dużo mniej prawdopodobne niż w gminach osiągających niższe dochody ogółem na mieszkańca; z tego powodu gminy te nie należą do grupy trzeciej obejmującej gminy o najniższym poziomie wykorzystania środków zwrotnych.

\section{Podsumowanie}

Analiza problemu prowadzi do wniosku, że wykorzystanie środków zwrotnych zwiększa możliwości gmin w zakresie realizacji inwestycji. Ze względu jednak na rozmaite czynniki zewnętrzne i wewnętrzne intensywność korzystania ze źródeł zewnętrznych (środków zwrotnych) przy finansowaniu inwestycji kształtuje się na różnym poziomie w poszczególnych gminach. Zbadanie gmin województwa małopolskiego pod względem poziomu wykorzystania środków zwrotnych pozwoliło na wyodrębnienie trzech grup gmin, podobnych pod względem wskaźników charakteryzujących wykorzystanie środków zwrotnych. Najliczniejsza grupa objęła 81 gmin, które rzadko wykorzystują możliwości finansowania projektów inwestycyjnych ze środków zwrotnych. W grupie dominowały gminy wiejskie oraz miejsko-wiejskie.

Na podstawie danych liczbowych i przyjętych wskaźników nie potwierdzono hipotezy badawczej, mówiącej, że gminy miejskie częściej niż inne realizują inwestycje z wykorzystaniem środków zwrotnych. Zakres czasowy przeprowadzonej analizy obejmował tylko 2014 r., a obliczenia zostały ograniczone do trzech wskaźników. Rozszerzenie przeprowadzonych badań mogłaby stanowić analiza uwzględniająca dodatkowe wskaźniki opisujące wykorzystanie środków zwrotnych przez gminy, która objęłaby okres kilku lat i inne województwa lub analiza różnych czynników warunkujących wykorzystanie zwrotnych źródeł finansowania.

\section{Literatura}

Bankowo-finansowa obstuga jednostek samorzqdu terytorialnego [2008], red. B. Filipiak, S. Flejtarski, CeDeWu, Warszawa.

Czempas J. [2013], Skłonność jednostek samorzqdu terytorialnego do inwestowania. Ujęcie ilościowe na przykładzie miast na prawach powiatu województwa ślaskiego, Wydawnictwo Uniwersytetu Ekonomicznego w Katowicach, Katowice.

Czerwonka L. [2015], Behawioralne aspekty decyzji inwestycyjnych przedsiębiorstw, Wydawnictwo Uniwersytetu Gdańskiego, Gdańsk.

Filipiak B. [2014], Adekwatność zródeł finansowania jednostek samorzqdu terytorialnego, „Finanse Komunalne”, nr 1-2.

Grabiński T., Sokołowski A. [1984], Z badań nad efektywnościq wybranych procedur taksonomicznych, „Zeszyty Naukowe Akademii Ekonomicznej w Krakowie”, nr 181. 
Graczyk M. [2008], Zarzqdzanie inwestycjami komunalnymi. Dobra praktyka w pozyskiwaniu funduszy europejskich, Oficyna Wydawnicza Branta, Bydgoszcz-Zielona Góra.

Guziejewska B. [2008], Zewnętrzne źródła finansowania samorzqdu terytorialnego. Teoria a praktyka, Wydawnictwo Uniwersytetu Łódzkiego, Łódź.

Hermaszewski J. [2006], Istota inwestycji lokalnych i ich rola w rozwoju gminy [w:] Rola samorzqdu w zarzqdzaniu rozwojem lokalnym i regionalnym, red. M. Adamowicz, PWZS, Biała Podlaska, www.hermaszewski.glogow.pl (data dostępu: 10.01.2016).

Jastrzębska M. [2009], Zarzq̨dzanie długiem jednostek samorzqdu terytorialnego, Wolters Kluwer, Warszawa.

Kurek H., Zielińska H. [2007], Inwestycje komunalne i główne determinanty ich rozwoju, „Zeszyty Naukowe Uniwersytetu Ekonomicznego w Krakowie”, nr 752.

Malina A. [2004], Wielowymiarowa analiza przestrzennego zróżnicowania struktury gospodarki Polski według województw, Wydawnictwo Akademii Ekonomicznej w Krakowie, Kraków.

Młodak A. [2006], Analiza taksonomiczna w statystyce regionalnej, Difin, Warszawa.

Nowe zarzqdzanie publiczne w polskim samorzqdzie terytorialnym [2005], red. A. Zalewski, Szkoła Główna Handlowa, Warszawa.

Suchecki B. [2010], Ekonometria przestrzenna, Wydawnictwo C.H. Beck, Warszawa.

Ustawa z dnia 27 sierpnia 2009 r. o finansach publicznych, Dz.U. nr 157 poz. 1240 ze zm.

Węgrzyn J. [2013], Przesłanki podejmowania inicjatyw partnerstwa publiczno-prywatnego - analiza porównawcza na przykładzie wybranych gmin województwa małopolskiego, ,Zeszyty Naukowe Uniwersytetu Ekonomicznego w Krakowie”, nr 913.

Wiewióra M. [2009], Prawne ograniczenia w zaciqganiu kredytów i pożyczek przez jednostki samorzqdu terytorialnego $w$ Polsce na tle rozwiqzań stosowanych $w$ wybranych krajach europejskich, Materiały i Studia, z. 239, Narodowy Bank Polski, Warszawa.

Wiśniewski M. [2011], Ocena zdolności kredytowej gminy, Difin, Warszawa.

Wyrok w imieniu Rzeczypospolitej Polskiej z dnia 28 października 2015 r. Sygn. akt K 21/14.

Zielińska E., Ostrowska E. [2013], Uwarunkowania behawioralne decyzji inwestycyjnych, „Zarządzanie i Finanse”, R. 11, nr 2, cz. 4.

Zielonka P. [2008], Behawioralne aspekty inwestowania na rynku papierów wartościowych, CeDeWu, Warszawa.

Zioło M. [2012], Modelowanie źródeł finansowania inwestycji komunalnych a efektywność wydatków publicznych, CeDeWu, Warszawa.

\section{The Use of Repayable Funds for Municipality Investments in Małopolska Province}

(Abstract)

The main objective of this study was to identify the determinants of the choice of repayable funds to finance investments made by municipalities in Poland and to assess the use of repayable funds by the municipalities of Małopolska Province. According to the research hypothesis, urban communities more often than other types of municipalities finance their investments by repayable funds. 
To achieve the article's objectives and test the hypothesis, an analysis of the subject literature and empirical research was carried out based on data from Poland's Central Statistical Office and the Regional Chamber of Audit in Cracow. Cluster analysis was performed in order to verify the hypothesis. The objects of this study were all 182 of the municipalities in Małopolska Province.

Keywords: repayable funds, municipality investments, investment financing, community. 